\title{
PENINGKATAN KOMPETENSI PROFESIONAL KONSELOR DALAM APLIKASI INSTRUMENTASI MELALUI LAYANAN PENGUASAAN KONTEN (Penelitian Tindakan Layanan Di SMP dan MTS se-Kota Padang Panjang)
}

\author{
Dasril \\ Program Studi Bimbingan dan Konseling, Jurusan Tarbiyah STAIN Batusangkar \\ Korespondensi: Perumahan Dobok Indah Blok C.1 No.5 Piliang Lima Kaum, \\ Batusangkar, Tanah Datar \\ Email: dasril.batusangkar.@gmail.com
}

\begin{abstract}
The aim of this research was to describe and improve a professional councellor's competency in applying the instrument of AUM PTSDL through services of content mastery. This research was an action research. The subject of this research were 20 junior high school councellors who were accomodated in MGMP (Musyawarah Guru Pembimbing) in Padang Panjang regency. This research applied cyclical process that consisted of some cycles. Therefore, in this research plan, action, observation, and reflection were done in two cycles depended on the achievement of the research objective. The result of this research showed that services of content mastery could improve the councellors' competency in applying the instrument of AUM PTSDL.
\end{abstract}

Kata kunci: kompetensi profesional, aplikasi instrumentasi, guru pembimbing, layanan penguasaan konten

\section{PENDAHULUAN}

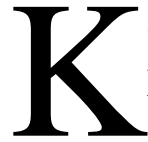

onselor adalah tenaga pendidik profesional yang telah menyeleaikan pendidikan akademik strata satu (S-1) program studi Bimbingan dan Konseling dari perguruan tinggi penyelenggara program pengadaan tenaga kependidikan yang terakreditasi. Sedangkan bagi individu yang menerima pelayanan profesi bimbingan dan konseling disebut konseli atau klien, dan pelayanan bimbingan dan konseling pada jalur pendidikan formal dan nonformal diselenggarakan oleh konselor.

Konselor atau juga sering disebut guru pembimbing mempunyai tugas yang berbeda dengan guru mata pelajar- an. Secara garis besar, konselor mempunyai tugas dan tanggung jawab menangani beragam masalah siswa, misalnya (1) masalah kesulitan belajar, yaitu metode belajar dan fasilitas belajar; (2) kelanjutan sekolah bagi peserta didik; (3) pemilihan jabatan; (4) penyesuaian diri terhadap sekolah, keluarga, masyarakat dan diri sendiri; (5) sosial, ekonomi dan kesehatan; (6) penggunaan waktu luang; dan (7) masalah-masalah kepribadian.

Untuk mengetahui berbagai masalah yang dialami oleh siswa konselor mesti aktif mengungkapan masalah siswa. Dalam profesi konseling untuk mengungkap masalah siswa awalnya dilakukan secara sederhana, yaitu hanya 
dengan memberikan angket atau wawancara lansung dengan siswa tentang masalah yang mereka alami. Semenjak tahun 1997, disusun alat pengungkap masalah siswa berbasis teknologi yaitu Instrumen AUM Umum dan AUM PTSDL yang sudah dengan sistem komputer.

Setelah adanya instrumen AUM di atas maka semenjak tahun 1997 sebagian besar sekolah sudah mulai menggunakan AUM untuk mengungkap masalah umum dan masalah belajar siswa. Namun di samping itu ternyata masih ada juga konselor atau guru pembimbing yang belum memamfaatkan teknologi AUM untuk mengungkap masalah siswa. Di antara konselor yang belum memanfaatkan AUM tersebut adalah konselor yang tergabung dalam MGP (Musyawarah Guru Pembimbing) SLTP- Se Kota Padang Panjang.

Dari hasil wawancara penulis dengan koordinator Guru Pembimbing SMP/MTS Kota padang panjang diperoleh informasi bahwa sebagian besar dari guru pembimbing di Padang Panjang masih mengalami kesulitan dalam memamfaatkan teknologi AUM untuk mengungkapkan permasalahan yang dialami oleh siswa asuh meraka, walaupun sebelumnya sudah mengikuti berbagai pelatihan tentang pemamfaatan instrumen tersebut.

Menurut Prayitno (1987: 14) ada beberapa permasalahan operasional dalam pelayanan bimbingan dan konseling di antaranya masalah insidental menyangkut aspek ruang dan waktu yang terbatas. Artinya seringkali pelayanan bimbingan dan konseling bertitik tolak dari masalah yang dirasakan siswa sekarang, namun pada hakikatnya pelayanan itu sendiri menjangkau dimensi waktu yang lebih luas, yaitu yang lalu, sekarang dan yang akan datang. Konselor tidak hanya menunggu klien datang mengungkapkan permasalahannya saja tetapi juga mesti berupaya pro aktif dalam mengungkapkan apa yang dialami siswa.

Sejalan dengan pendapat prayitno di atas menurut Ardimen (2003: 58-65) menegaskan bahwa profesi bimbingan dan konseling merupakan profesi yang membutuhkan keahlian dan keterampilan tersendiri yang tidak bisa dilakukan semua orang, disamping itu untuk mencapai keterampilan tersebut diperlukan laboratoriumyang berfungsi untuk menyelenggarakan latihan layanan bimbingan dan konseling.

Berdasarkan hal tersebut di atas maka penulis tertarik untuk melihat bagaimana kompetensi profesional konselor SMP/MTS se-Kota Padang Panjang dalam Aplikasi Instrumentasi khususnya instrument AUM Umum dan AUM PTSDL dan sekaligus berupaya memberikan layanan penguasaan konten untuk meningkatkan kemampuan mereka dalam Aplikasi Instrumen tersebut.

Adapun tujuan penelitian ini secara umum adalah untuk meningkatkan kompetensi profesional konselor dalam aplikasi instrumentasi Sedangkan yang menjadi tujuan secara khusus penelitian ini adalah untuk mengetahui dan mendapatkan data tentang: 1) Kompetensi professional konselor dalam mengadministrasikan AUM PTSDL, 2) Kompetensi professional konselor dalam mengolah data AUM PTSDL, 3) Kompetensi professional konselor dalam menganalisis dan mengimformasikan hasil pengolahan data AUM, 4) Peningkatan kompetensi professional konselor dalam aplikasi instrumentasi AUM melalui layanan penguasaan konten

\section{KAJIAN TEORI}

\section{Profil Konselor}

Konselor adalah tenaga pendidik profesional yang telah menyelesaikan pendidikan akademik strata satu (S-1) program studi Bimbingan dan Konseling 
dan program Pendidikan Profesi Konselor dari perguruan tinggi penyelenggara program pengadaan tenaga kependidikan yang terakreditasi. Sedangkan bagi individu yang menerima pelayanan profesi bimbingan dan konseling disebut konseli atau klien, dan pelayanan bimbingan dan konseling pada jalur pendidikan formal dan nonformal diselenggarakan oleh konselor.

Menurut Munro, (1983: 29) "walaupun tidak ada pola yang tegas terhadap karakteristik konselor namun sekurang-kurangnya seorang konselor memiliki sifat luwes, hangat, dapat menerima orang lain, terbuka dan merasakan penderitaan orang lain, tidak mau menang sendiri, dan objektif.

Sejalan dengan pendapat di atas Willis (2004: 86) juga menyimpulkan bahwa karakteristik dari konselor profesional itu, antara lain:

a. Beriman, bertaqwa

b. Menyenangi manusia

c. Komunikator yang terampil

d. Memiliki ilmu dan wawasan tentang manusia, sosial budaya yang merupakan nara sumber yang kompeten

e. Fleksibel, tenang dan sabar

f. Menguasai keterampilan teknik, memiliki institusi

g. Memahami etika profesi

h. Respek, jujur, asli, menghargai, tidak menilai

i. Empati, memahami, menerima, hangat, bersahabat

j. Fasilitator, motivator

k. Emosi, stabil, pikiran jernih, cpat dan mampu

1. Objektif, rasional, logis, konkrit

$\mathrm{m}$. Konsisten dan tanggung jawab.

Dari uraian di atas jelaslah bahwa karakteristik konselor yang begitu banyak dan yang harus ada dalam diri seorang konselor tersebut itulah yang nantinya akan mendukung terhadap kompetensi profesional seorang konselor dalam pelayanan bimbingan dan konseling. Karena seorang konselor merupakan sebagai panutan dan suri tauladan yang baik bagi siswa atau kliennya.

Sedangkan tugas pokok konselor menurut Anas Salahudin (2010:106) seorang konselor mempunyai tanggung jawab yang tidak ringan, misalnya mengadakan penelitian terhadap lingkungan sekolah, membimbing anakanak, serta memberikan saran-saran yang berharga. Menurut HM Umar dan Sartono (1998: 42) tugas seorang konselor di sekolah adalah membantu kepala sekolah beserta stafnya dalam menyelenggarakan kesejahteraan sekolah, sehubungan dengan hal tersebut konselor sekolah mempunyai tugas mengadakan penelitian atau observasi terhadap situasi atau keadaan sekolah, baik mengenai peralatan, tenaga, penyelanggara maupun aktifitas lainnya.

Dari uraian di atas terlihat di antara tugas konselor adalah menangani masalah kesulitan belajar siswa. Untuk bisa menangani masalah kesulitan belajar siswa tentu konselor mesti melakukan aplikasi instrumentasi non tes, yaitu mengadministrasikan AUM Umum dan AUM PTSDL.

Untuk menegakkan sosok profesinya, konselor dituntut untuk menguasai berbagai kompetensi profesional dengan posisi serta tugas pokok dan kegiatan profesionalnya. (Abkin: 2005 :4)

a. Sebagai pendidik, konselor d.ituntut menguasai kompetensi dasar proses pembelajaran melalui bahasa dan penerapan pendekatan, metode dan kegiatan pendukung pelayanan konseling. kompetensi profesional konselor terbentang dalam spektrum kompetensi keilmuan, keahlian dan prilaku profesi 
b. Spektrum profesi. Dalam spektrum kompetensi konselor trdapat tiga pilar kompetensi, yaitu kompetensi keilmuan, kompetensi keahlian/keterampilan dan kompetensi prilaku profesi. Ketiga kompetensi tersebut harus dikuasai oleh konselor. (Abkin: 2005:

4)

Dari uraian tentang spektrum profesi di atas terlihat bahwa kompetensi profesional konselor dalam aplikasi instrumentasi yang menjadi fokus penelitian peneliti, merupakan salah satu kompetensi keahlian atau keterampilan yang mesti dikuasai oleh konselor

\section{Aplikasi Instrumentasi}

Aplikasi instrumentasi merupakan kegiatan mengumpulkan data tentang diri peserta didik dan lingkungannya, melalui aplikasi berbagai instrument, baik instrument tes maupun instrument non tes. (PMPTK Depdiknas: 2008 :11)

Tujuan dari Aplikasi Instrumentasi secara khusus adalah diperolehnya data hasil pengukuran terhadap kondisi tertentu klien. Data itu digunakan sebagai bahan pertimbangan penyelengaraan layanan atau menjadi isi layanan.Secara Khusus tujuan Aplikasi Instrumentasi dikaitkan dengan fungsi2 konseling, yang didominasi oleh 1) Fungsi pemahaman, 2) Fungsi Pengentasan, 3). Fungsi Pengembangan dan pemeliharaan dan 4) Fungsi advokasi.

Kegiatan aplikasi instrumentasi mensinergikan tiga komponem pokok, yaitu instrument, responden dan pengguna. Pertama Instrumen, ada dua hal pokok yang mendapat perhatian yang seksama, yaitu, pertama materi yang hendak diungkapkan oleh instrument, kedua bentuk instrumen, kedua hal itu tersebut menyatu dalam sebuah instrument atau alat ukur yang dikonstruksi secara cermat mengikuti syarat-syarat tertentu. Kedua responden, ialah mereka yang mengerjakan instrument, baik tes maupun non tes melalui pengadmi- nistrasian yang dilakukan oleh penyelenggara (konselor). Ketiga Pengguna Instrumen.

Dalam operasionalisasi Aplikasi Instrumentasi seorang konselor yang akan melaksanakan kegiatan pendukung aplikasi instrumentasi mesti memahami bagaimana operasionalisasi dari instrument tersebut. Menurut Prayitno (2004: 23) Operasionalisasi dari instrument itu ada 6 tahap yaitu: 1) Perencanaan, 2) Pelaksanaan, 3) Evaluasi, 4) Analisis Hail Evaluasi, 5), Tindak Lanjut dan 6) Laporan.

Pada tahap pelaksanaan ada beberapa keterampilan yang mesti kuasai oleh koselor antara lain: 1) Mengkomunikasikan rencana dengan pihak terkait, 2) Mengorganisasikan kegiatan instrumentasi, 3) Mengadministrasikan instrument, mengolah jawaban responden, menafsirkan hasil instrumentasi, dan menetapkan arah penggunaan hasil instrumentasi

\section{Layanan Penguasaan Konten}

Layanan penguasaan konten (PKO) merupakan layanan bantuan kepada individu (sendiri-sendiri ataupun kelompok) untuk menguasai kemampuan atau kompetensi tertentu melaui kegiatan belajar. Tujuan layanan PKO ialah dikuasainya suatu konten tertentu. Penguasaan konten ini perlu bagi individu untuk menambah wawasan dan pemahaman, mengerahkan penilaian dan sikap, menguasai cara-cara atau kebiasan tetentu, untuk memenuhi kebutuhannya dan mengatasi masalahnya. (Prayitno 2004: 10)

Layanan penguasaan konten dapat dilakukan untuk mengembangkan berbagai hal yang kemudian dikemas menjadi topik bahasan, bahan latihan dan atau isi kegiatan yang diikuti oleh peserta layanan PKO. Konten dalam hal ini bisa temasuk kemampuan atau kompetensi konselor dalam aplikasi instrumentasi. 


\section{METODE PENELITIAN}

\section{Jenis Penelitian}

Penelitian ini merupakan penelitian tindakan kelas (Classroom Action Research), karena merupakan suatu bentuk kajian yang bersifat reflektif oleh pelaku tindakan. Menurut Hopkins (1992) dalam Sukidi (2002: 13) PTK disebut dengan classroom action research. Pada keilmuan bimbingan dan konseling lebih dikenal dengan Penelitian Tindakan Layanan (PTL), karena merupakan suatu bentuk kajian yang bersifat reflektif oleh prilaku tindakan. Penelitian Tindakan ini dilaksanakan untuk membantu konselor/Guru Pembimbing untuk meningkatkan kemampuan mereka dalam menggunakan Instrumen AUM (Alat Ungkap Masalah) Umum dan PTSDL melalui layanan Penguasaan Konten.

Subjek penelitian adalah Konselor/ Guru Pembimbing SMP/MTS se-Kota Padang Panjang yang mengalami kesulitan dalam aplikasi instrumentasi jumlahnya 20 orang. Subjek akan dipilih dan diidentifikasi masalah-masalah apa yang mereka alami berkaitan dengan konten-konten aplikasi instrumentasi AUM.

\section{Prosedur Penelitian}

Untuk mencapai tujuan-tujuan penelitian sebagaimana tersebut di atas, maka penelitian ini akan terdiri atas beberapa siklus. Dalam satu siklus akan terdiri dari beberapa tahap, yaitu : tahap perencanaan, tahap tindakan, tahap pengamatan dan tahap refleksi. Setiap tahap dilakukan berulang-ulang (bersiklus) sampai tujuan dicapai. Dalam penelitian ini siklus dilakukan minimal dua siklus tergantung kepada perkembangan di lapangan. Untuk masing-masing siklus kegiatan akan dirinci menjadi langkah-langkah sebagai berikut:

\section{Siklus 1}

Perencanaan, dalam siklus ini diawali dengan diskusi antara peneliti dengan konselor/Guru Pembimbing SMP/MTS kota Padang Panjang untuk mengidentifikasi konten-konten yang bermasalah, merancang hand out materi layanan PKO dan menyiapkan sarana pendukung seperti buku AUM, lembar jawaban, lembar observasi, dan lembar kerja.

Setelah adanya perencanaan, maka kegiatan selanjutnya adalah memberikan tindakan (action). Tindakan yang dilakukan adalah pemberian materi layanan penguasaan konten berkaitan dengan aplikasi instrumentasi. Dalam pengamatan, peneliti melakukan analisis terhadap peningkatan skil konselor dalam aplikasi instrumentasi. Sejalan dengan langkah pengamatan ini, dilakukan langkah refleksi, yakni merenungkan, memikirkan dan menilai segala tindakan yang dilakukan untuk selanjutnya direvisi. Dengan demikian selesailah siklus pertama dari penelitian tindakan ini.

\section{Siklus 2}

Perencanaan, pada siklus 2 ini akan diawali dengan mendiskusikan kompetensi mana yang sudah ada peningkatan pada siklus 1 . Kegiatan perencanaan pada siklus 2 ini adalah mendiskusikan materi program dan kendalakendala pelaksanaannya. Dari diskusi akan dilakukan revisi-revisi yang mengarah pada penyempurnaan layanan PKO.

Adapun tindakan, yang diambil dalam siklus 2 ini adalah memantapkan penguasaan keterampilan konselor/Guru Pembimbing dalam mengadministrasikan, mengolah dan menganalisis data AUM. Pengamatan, yang dilakukan pada siklus 2 ini dimaksudkan untuk melihat sejauh mana terjadinya peningkatan penguasaan kompetensi pro- 
fessional konselor dalam mengadministasikan, mengolah dan menganalisis data AUM. Secara skematis prosedur penelitian ini dapat dilihat dalam bagan berikut:

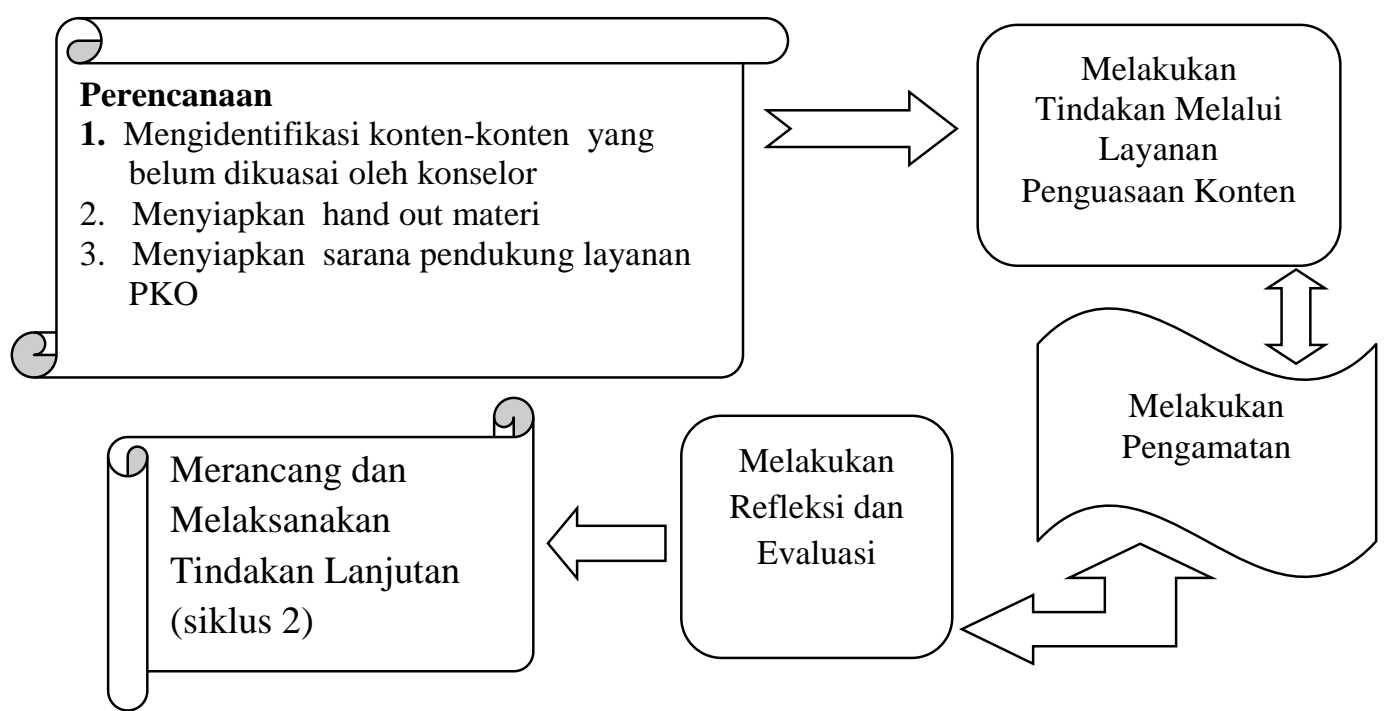

Bagan 1: Prosedur Penelitian

Untuk mengumpulkan data hasil penelitian ini digunakan teknik wawancara, angket dan observasi. Wawancara merupakan salah satu bentuk teknik pengumpulan data yang banyak digunakan dalam penelitian deskriptif kualitatif dan kuantitatif (Nana Saodih: 2009: 216)

\section{Teknik Analisis Data}

Analisis data merupakan langkah kegiatan yang sangat penting dalam setiap kali melakukan penelitian. Semua data yang terkumpul tidak akan berarti kalau tidak dianalisis. Hasil analisis data akan memberikan gambaran, arah dan tujuan dan maksud penelitian. Dalam penelitian ini analisis data dilakukan untuk melihat aktifitas dan kemampuan konselor dalam aplikasi instrumentasi dengan skor sebagai berikut:

Tabel 1:

Penilaian Kompetensi Profesional Konselor dalam

Aplikasi Instrumentasi

\begin{tabular}{cl}
\hline Skor & \multicolumn{1}{c}{ Level / Kategori } \\
\hline 4 & Superior/ Sangat mampu/ memuaskan/ sangat baik \\
\hline 3 & Mampu/ baik/memuaskan dengan sedikit kekurangan \\
\hline 2 & Cukup mampu dengan banyak kekurangan \\
\hline 1 & Sangat tidak mampu/ sangat tidak memuaskan \\
\hline
\end{tabular}

Hasil penilaian aktifitas kompetensi profesional konselor dalam aplikasi instrumentasi setiap tindakan dimasukkan ke dalam tabel untuk menge- tahui peningkatan kompetensi professional konselor dalam aplikasi instrumentasi setiap aspek indikator yang dilatihkan pada proses kegiatan. 


\section{HASIL PENELITIAN DAN PEMBAHASAN}

Penelitian tindakan merupakan suatu proses yang dilakukan untuk menghendaki terjadinya perubahan dalam situasi tertentu, untuk menguji prosedur yang diperkirakan akan menghasilkan perubahan tersebut. Pada Bab ini penulis akan menyajikan hasil penelitian yang mengungkapkan peningkatan kompetensi profesional guru pembimbing SMPN dan MTS Se-Kota Padang Panjang dalam aplikasi instru- mentasi AUM PTSDL. Sebelum tindakan dilakukan, peneliti terlebih dahulu memberikan angket untuk mengetahui kompetensi profesional guru pembimbing dalam Aplikasi Instrumentasi AUM PTSDL. Dari 14 Guru Pembimbing yang terdaftar hanya 9 orang guru pembimbing yang dapat mengikuti kegiatan mulai dari pemberian angket awal sampai dengan pemberian tindakan siklus 1 dan siklus 2. Adapun Hasil pengolahan angket awal dapat dilihat pada tabel berikut:

Tabel 3

Kompetensi Profesional

Guru Pembimbing dalam Aplikasi Instrumentasi sebelum Tindakan

$$
\mathrm{N}=9
$$

\begin{tabular}{ccccc}
\hline No & $\begin{array}{c}\text { Skor Kemampuan } \\
\text { Aplikasi Instrumentasi }\end{array}$ & $\begin{array}{c}\text { Mutu Kemampuan } \\
\text { Aplikasi Instrumentasi }\end{array}$ & Frekuaensi & $\%$ \\
\hline 1 & $16-20$ & Sangat Baik & 0 & $0 \%$ \\
\hline 2 & $11-15$ & Baik & 3 & $33, \%$ \\
\hline 3 & $6-10$ & Cukup & 6 & $67 \%$ \\
\hline 4 & $1-5$ & Kurang & 0 & $0 \%$ \\
\hline
\end{tabular}

Berdasarkan tabel 3 di atas dapat dipahami bahwa dari 9 orang guru pembimbing belum ada yang mutunya dalam aplikasi instrumentasi masuk dalam katagori sangat baik, 3 orang $(33 \%)$ klasifikasi baik, 9 orang (75\%) klasifikasi cukup. Dari data tersebut dapat dipahami bahwa mutu konselor dalam aplikasi instrumentasi perlu ditingkatkan. Salah satu cara meningkatkan adalah melalui layanan penguasaan konten

\section{Peningkatan Kompetensi Profesional dengan Layanan Penguasaan Konten pada Siklus I}

Kegiatan penelitian pada siklus pertama ini terdiri atas empat tahap kegiatan yaitu, tahap perencanaan, pelaksanaan tindakan, pengamatan/observasi, dan refleksi seperti dalam uraian berikut:

\section{Perencanaan}

Pada tahap perencanaan ini peneliti melakukan kegiatan untuk menjadi pedoman dan bahan pada kegiatan tahap pelaksanaan tindakan, yaitu:

a. Menetapkan subjek atau peserta layanan. Guru Pembimbing SMPN/MTS se-Kota Padang Panjang ditetapkan sebagai peserta layanan berdasarkan wawancara penulis dengan koordinator GP, yang mengemukan keluhan GP dalam hal aplikasi instrumentasi nontes, khususnya AUM PTSDL lebih kurang 14 orang

b. Masalah yang dialami berkaitan dengan aplikasi instrumentasi antara lain, 1) cara mengadministrasikan, 2) cara mengolah secara manual 3) cara mengolah dengan komputer, 4) cara mempre- 
sentasikan pada siswa serta 5) cara menganalisisnya.

c. Setelah masalah diketahui peneliti menyiapkan bahan untuk layanan penguasaan konten ,peneliti membuat kesepakatan dengan koordinator Guru Pembimbing untuk menyepakati waktu pelaksanaan layanan.

d. Langkah berikutnya peneliti menetapkan proses dan langkahlangkah pelaksanaan tindakan

e. Menetapkan dan menyiapkan fasilitas layanan, termasuk media dengan perangkat keras dan lunaknya

f. Menyiapkan kelengkapan administrasi

g. Materi tindakan layanan penguasaan konten yang akan diberikan pada tahap pertama ini berkaitan dengan keterampilan dalam mengadministrasi instrumentasi AUM dan keterampilan dalam mengolah hasil pengadministrasian secara manual.

\section{Pelaksanaan Tindakan}

Pada tahap pelaksanaan tindakan siklus pertama ini dilaksanakan dua materi layanan penguasaan konten yaitu keterampilan mengadministrasikan dan keterampilan mengolah data AUM PTSDL secara manual. Untuk itu pada Tahap ini peneliti melakukan skenario dan kegiatan dalam kelompok MGP-BK se-Kota Padang Panjang sebagai berikut:

a. Memberikan prites kepada guru pembimbing tentang wawasan dan keterampilan mereka dalam mengadministrasikan AUM PTSDL

b. Melatih guru pembimbing dalam mengadministrasikan AUM PTSDL

c. Melatih guru pembimbing mengolah data AUM PTSDL (Dalam hal ini datanya penulis bawa lansung)

d. Pelatihan mengolah data dilakukan secara klasikal dimana masingmasing guru pembimbing diberi tugas mengolah data seorang siswa.

e. Pengolahan dilanjutkan dengan mengolah data secara AUM PTSDL secara kelompok.

\section{Pengamatan}

Peneliti di samping lansung memberikan pelatihan tentang cara mengolah data AUM PTSDL secara manual, peneliti juga melakukan pengamatan terhadap aktifitas guru pembimbing dalam mengolah data AUM dan memberikan bantuan jika diperlukan atau ada yang kurang dipahami oleh guru pembimbing.

Hal-hal yang diamati untuk mengetahui terjadinya peningkatan kompetensi propessional guru pembimbing berkaitan dengan keterampilan mengadministrasikan dan mengolah data AUM PTSDL secara manual sebagai berikut:

a. Keterampilan guru pembimbing dalam mengadministrasikan AUM PTSDL, mulai dari cara menyampaikan apa mengapa AUM PTSDL, cara membagikan buku AUM dan mengisi AUM PTSDL oleh siswa sampai dengan bagaimana siswa mengembalikan buku yang sudah diisi.

b. Keterampilan guru pembimbing dalam mengolah data AUM PTSDL secara manual, yang dilihat antara lain: 1) cara guru pembimbing menandai setiap nomor yang disilangi siswa dengan $\mathrm{K} 1$, K2 atau KM. 2) Bagaimana guru merekap semua kunci untuk ke lima bidang aspek pada kolom rekap dan 3) bagaimana guru pembimbing memindahkan hasil pada lembaran hasil pengolah secara individu. 4) bagaimana kerja sama guru pembimbing dalam menyusun rekap untuk data kelompok dan melihat hasil pengolahan AUM PTSDL secara kelompok. 


\section{Refleksi}

Pada tahap ini kegiatan yang dilakukan adalah menganalisis, mensintesis hasil pengamatan selama proses pelatihan. Pada tahap ini dirumuskan perlakuan yang harus diperbaiki, dipertahankan dan yang akan dibuang. Pada tahap ini juga didiskusikan ke- berhasilan atau kegagalan perlakuan untuk menentukan perlu atau tidaknya siklus selanjutnya.

Dalam mengadministrasikan AUM PTSDL dan mengolah data AUM secara manual dari 9 orang guru pembimbing terlihat ada peningkatan. Lebih lanjut dapat dilihat pada tabel 3 berikut :

Tabel 3

Kompetensi Guru Pembimbing

dalam Aplikasi Instrumentasi AUM PTSDL setelah Tindakan 1

$\mathrm{N}=9$

\begin{tabular}{ccccc}
\hline No & $\begin{array}{c}\text { Skor Kemampuan } \\
\text { Aplikasi Instrumentasi }\end{array}$ & $\begin{array}{c}\text { Mutu Kemampuan } \\
\text { Aplikasi Instrumentasi }\end{array}$ & $\begin{array}{c}\text { Sebelum } \\
\text { Tindakan }\end{array}$ & $\begin{array}{c}\text { Setelah } \\
\text { Tindakan 1 }\end{array}$ \\
\hline 1 & $16-20$ & Sangat Baik & 0 & 0 \\
\hline 2 & $11-15$ & Baik & 3 & 9 \\
\hline 3 & $6-10$ & Cukup & 6 & 0 \\
\hline 4 & $1-5$ & Kurang & 0 & 0 \\
\hline
\end{tabular}

Dari tabel di atas terlihat ada peningkatan kompetensi professional guru pembimbing berkaitan dengan aplikasi instrumentasi dalam aspek mengadminstrasikan AUM dan mengolah data secara manual. Dimana sebelum diberikan tindakan mutu kompetensi professional guru pembimbing dalam aplikasi instrumentasi terlihat dari 9 orang guru pembimbing 6 orang mutunya cukup dan 3 orang yang baik, setelah pemberian tindakan pertama pada siklus pertama, mutu keterampilan guru pembimbing naik dari yang 6 orang yang semuala berada pada katagori cukup naik keenamnya pada katagori baik. Sehingga ke sembilan guru pembimbing mutunya berada pada katagori baik.

Idealnya mutu kompetensi professional guru pembimbing dalam aplikasi instrumentasi tentu sangat baik, oleh karena itu peneliti memahami perlunya siklus kedua untuk mencapai kompetensi professional guru pembimbing yang sangat baik/ sangat mampu dalam aplikasi instrumentasi khususnya AUM PTSDL. Maka dari itu perlu siklus kedua untuk meningkatkan kompetensi professional guru pembimbing dalam aplikasi instrumentasi AUM PTSDL. Berdasarkan pengamatan peneliti sekaligus sebagai pemberi layanan, guru pembimbing sangat serius dalam mengikuiti latihan,

Berdasarkan hasil tindakan pada siklus pertama, dimana terlihat masih rendahnya kompetensi professional guru pembimbing dalam aplikasi instrumentasi AUM PTSDL, setelah dilihat pada masing-masing aspek keterampilan ternyata rendahnya berada pada aspek mengimformasikan hasil pengolahan dan menganalisis hasil pengolahan tersebut. Berdasarkan hal tersebt maka penulis menganggap sangat perlunya dilanjutkan pada tindakan ke dua pada siklus II.

\section{Peningkatan Kompetensi Professional dengan Layanan Penguasaan Kontens Siklus Kedua}

Untuk peningkatan kompetensi professional melalui layanan penguasaan konten pada siklus kedua, penulis mengikuti langkah-langkah sebagai berikut: 


\section{Perencanaan}

Pada tahap perencanaan ini kegiatan yang penulis lakukan adalah sebagai berikut:

a. Menentukan materi yang akan disajikan dalam rangka meningkatkan kompetensi guru pembimbing dalam aplikasi instrumentasi AUM PTSDL

b. Merancang kegiatan yang menarik bagi guru pembimbing dalam melatih mereka untuk mengimformasikan hasil pengolahan AUM PTSDL

\section{Pelaksanaan Tindakan}

Tahap pelaksanaan tindakan dalam penelitian ini adalah sebagai berikut:

a. Memberikan hand out kepada tiap guru pembimbing

b. Menyajikan materi tentang bagaimana mengimformasikan dan menganalisis hasil pengolahan AUM dengan menampilkan hasil pengolahan individual dan kelompok.

c. Penyaji/peneliti sendiri memberikan penjelasan tentang bagaimana cara mengimformasikan dan menganalisis hasil AUM PTSDL individual dan kelompok

d. Guru pembimbing bergantian ke depan latihan mengimformasikan dan menganalisis hasil pengolahan AUM PTSDL.

\section{Pengamatan}

Penelliti lansung melakukan pengamatan terhadap aktifitas guru pembimbing selama berlansungnya kegiatan layanan. Dari pengamatan penulis terlihat keseriusan guru pembimbing dalam mengikuti kegiatan. Setiap guru pembimbing diminta untuk tampil didepan kelas untuk praktek membacakan temuan hasil pengolahan AUM PTSDL dan analisisnya.

\section{Refleksi}

Refleksi yaitu mengingat dan merenungkan kembali suatu tindakan persis yang telah dicatat dalam lembaran observasi. Tahap refleksi ini adalah untuk melihat apakah dibutuhkan siklus selanjutnya. Dilihat dari pengamatan penulis dan angket yang penulis berikan pada guru pembimbing setelah tindakan kedua, terlihat dan tercatat adanya peningkatan kompetensi professional berkaitan dengan keterampilan guru pembimbing dalam aplikasi instrumentasi AUM PTSDL, dengan datanya dapat dilihat pada tabel 5 berikut:

Tabel 5

Kompetensi Profesional Guru Pembimbing dalam Aplikasi Instrumentasi AUM PTSDL setelah Tindakan 2

$$
\mathrm{N}=9
$$

\begin{tabular}{cccccc}
\hline No & $\begin{array}{c}\text { Rentangan Skor } \\
\text { Kemampuan } \\
\text { Aplikasi } \\
\text { Instrumentasi }\end{array}$ & $\begin{array}{c}\text { Mutu } \\
\text { Kemampuan A } \\
\text { plikasi } \\
\text { Instrumentasi }\end{array}$ & $\begin{array}{c}\text { Sebelum } \\
\text { Tindakan }\end{array}$ & $\begin{array}{c}\text { Setelah } \\
\text { Tindakan 1 }\end{array}$ & $\begin{array}{c}\text { Setelah } \\
\text { Tindakan 2 }\end{array}$ \\
\hline 1 & $16-20$ & Sangat Baik & 0 & 0 & 4 \\
\hline 2 & $11-15$ & Baik & 3 & 9 & 5 \\
\hline 3 & $6-10$ & Cukup & 6 & 0 & 0 \\
\hline 4 & $1-5$ & Kurang & 0 & 0 & 0 \\
\hline
\end{tabular}

Dari tabel 5 di atas terlihat setelah diberikan tindakan pada siklus II adanya peningkatan mutu keterampilan guru pembimbing dalam aplikasi instrumentasi setelah tindakan kedua, dimana terlihat skor mutu keterampilan guru 
pembimbing yang pada tindakan pertama $100 \%$ berada pada baik, dan setelah tindakan kedua 4 orang mutunya naik menjadi katagori sangat baik dan 5 orang tetap pada katagori baik. Lebih lanjut setelah penulis olah dari jawaban angket masih terdapat kompetensi profesional konselor masih rendah pada aspek kemampuan mengolah secara komputer. Untuk pengolahan secara komputer ini tentunya memerlukan waktu yang lebih panjang. Setidaknya minimal mengolah dengan manusal mesti dikuasai oleh Guru Pembimbing.

Dari tabel di atas juga dipahami bahwasanya layanan penguasaan konten dapat meningkatkan kompetensi konselor dalam aplikasi instrumentasi AUM PTSDL. Dengan ini diharapkan ke depan bagaimana kinerja dari konselor sekolah SMP/MTS se-Kota padang Panjang dapat meningkat dan dapat senantiasa menggunakan instrumen tersebut sebagai salah satu alat untuk melihat bagaimana persoalan-persoalan belajar siswa mereka. Dengan menggunakan instrumen yang standar tersebut diharapkan permasalahan-permasalahan belajar siswa dapat diungkapkan. Dengan terungkapnya pemasalahan belajar siswa tentu guru pembimbing akan berupaya menyusun program baik secara individual, kelompok maupun klasikal dalam mengentaskan permasalahan belajar siswa.

Peningkatan kemampuan memang tidak hanya diharapkan dari pelatihan sesaat saja, yang tidak kalah pentingnya adalah komitmen dari konselor sekolah itu sendiri secara kontiniu senantiasa melakukan kegiatan pendukung berupa aplikasi instrumentasi. Kegiatan ini memiliki dua mamfaat seklaligus di samping dapat mengungkapkan masalah belajar siswanya dengan lebih tepat juga tentunya akan meningkatkan kemampuan mereka dalam aplikasi instrumentasi itu sendiri. Ternyata memang dari hasil wawancara penulis dengan beberapa orang guru pembimbing bahwa salah satu yang menyebabkan rendahnya kompetensi profesional dalam aplikasi instrumentasi adalah karena jarangnya konselor sekolah menggunakan instrumen tersebut dalam mengungkapkan masalah belajar siswa.

Dengan adanya penelitian tindakan ini diharapakan tentunya dapat meningkatkan kinerja konselor sekolah di lapangan.

\section{PENUTUP}

\section{Kesimpulan}

Berdasarkan hasil penelitian dan pembahasan yang telah diuraikan pada bab sebelumnya, maka dapat disimpulkan bahwa

1. Kompetensi profesional yang mesti dikuasai oleh guru pembimbing dalam aplikasi instrumentasi AUM PTSDL antara lain kompetensi dalam mengadministrasikan, kompetensi dalam mengolah data secara manual dan komputer serta kompetensi dalam mengimformasikan dan menganalisis

2. Kompetensi guru pembimbing dalam aplikasi instrumentasi sebelum tindakan ditemukan sebagian besar (75\%) cukup.

3. Kompetensi guru pembimbing setelah tindakan pertama seluruhnya berada pada katagori baik (100\%)

4. Kompentensi guru pembimbing dalam aplikasi instrumentasi setelah tindakan kedua sebagian $(55 \%)$ masih berada pada katagori baik dan $(45 \%)$ sudah meningkat menjadi sangat baik

5. Kompetensi guru pembimbing yang masih rendah dalam hal pengolahan data AUM secara komputer. 
6. Layanan penguasaan konten dapat meningkatkan kompetensi konselor dalam aplikasi instrumentasi.

\section{Saran}

Disarankan kepada guru pembimbing untuk senantiasa melaksanakan

\section{DAFTAR RUJUKAN}

ABKIN, 2005. Memantapkan Standar Profesi Bimbingan dan Konseling Indonesia Konvensi Nasional XIV Bimbingan dan Konseling Indonesia, Semarang.

Ardimen, Jurnal Ilmiah Ta'dib Vo.6 No 2 Desember 2003

Depdikbud. 1995. Kamus Bahasa Indonesia Kontemporer. Jakarta: Balai Pustaka

Direktorat Pembinaan Pendidikan Tenaga Kependidikan dan Ketenagaan Perguruan Tinggi, Dasar standardisasi Profesi Konseling. 2004.

Direktorat Jenderal Pendidikan Islam Depertemen Agama Republik Indonesia tahun 2006, UndangUndang dan Peraturan Pemerintah Republik Indonesia tentang Pendidikan.

Emzir. 2008. Metodologi Penelitian Pendidikan Kuantitatif dan Kualitatif. Jakarta: PT Raja Grafindo Persada aplikasi instrumentasi, khususnya AUM PTSDL dalam rangka mengungkapkan masalah belajar siswa dan menyusun program serta untuk meningkatkan kemampuan guru pembimbing dalam aplikasi inatrumentasi

Munro. 1983. Penyuluhan Suatu Pendekatan Berdasarkan Keterampilan. Jakarta: Ghalia Indonesia.

Nana Syaodih Sukmadinata, 2009, Metode Penelitian Pendidikan, Bandung : PT Remaja Rosdakarya

Prayitno. 1987. Profesionalisasi Konseling dan Pendidikan Konselor. Padang: IKIP. 2004. Seri Layanan Konseling L1-L9. Padang: UNP.

1997. Seri Pemandu Pelayanan Bimbingan dan Konseling di SMU. Padang: UNP.

2002. Profesi Kependidikan/ BK. Padang:UNP.

Standar Kualifikasi Akademik dan Kompetensi Konselor. Departemen Pendidikan Nasional Tahun 2008.

Sukidin dkk, 2002, Manajemen Penelitian Tindakan Kelas, Insan Cendekian

Sofyan S, Willis. 2004. Konseling Individual Teori dan Praktik. Bandung: Alfabeta. 